\title{
OBSERVATION ON BEACH EROSION AND CORAL DESTRUCTION BY REMOTE SENSING TECHNIQUES
}

by

\author{
DJOKOP. PRASENO ${ }^{1)}$ and SUKARNO ${ }^{1)}$
}

\begin{abstract}
Remote sensing techniques were used to observe beach erosion at Sengkidu Beach, Labuan Amuk, east coast of Bali. Erosion was caused by wave actions flowing over destructed coral reef. Aerial photography was found useful in obtaining first hand information of the destructed corals and its affects on the beach.
\end{abstract}

\section{INTRODUCTION}

Since the past, Indonesia has been collecting oceanographic data and informations from coastal areas, territorial waters, and adjacent seas. Lack of facilities, funds, and manpower, has limited the gathering of information about the sea, which covers $70 \%$ of the country's total territory.

The use of remote sensing techniques in oceanography in Indonesia started in 1973/74 when a project was set up by BAKOSURTANAL and USGS to test the possible applications of using multispectral photography for several disciplines, including oceanography (SzEKIELDA et al. 1974). This was followed in 1975 by using satellite data (ERTS- 1) to study the pollution problems in the Jakarta Bay (PRASE NO 1975).

In marine sciences the best results using remote sensing techniques were obtained for coastal areas (BROWN et al. 1971, BOWKER et al 1973, Ross 1973, WRIGHT et al 1973, ANDERSON et al 1973, HUNTER 1973, MASCARENHAS \& TANAKA 1974, SZEKIELDA et al 1974, PRASENO 1975, YOST et. al 1971). Satellite and aircraft became valuable because of the "abilities" to cover a wide area. It is, however, limited by the depth penetration capabilities of the spectral bands. The location of reefs, their distances from the coast, and their distributions can be mapped by using aerial photography. On some occasions the condition of reefs can also be studied.

This paper discusses one of the results obtained from Sengkidu Beach, Labuan Amuk, east of Bali during the 1974 project of remote sensing in Bali. The place is one of the sites where reefs are collected for lime and other construction materials.

1) National Institute of Oceanology. Indonesian Institute of Sciences. Jakarta, Indonesia. 
DJoko P. Praseno \& Sukarno

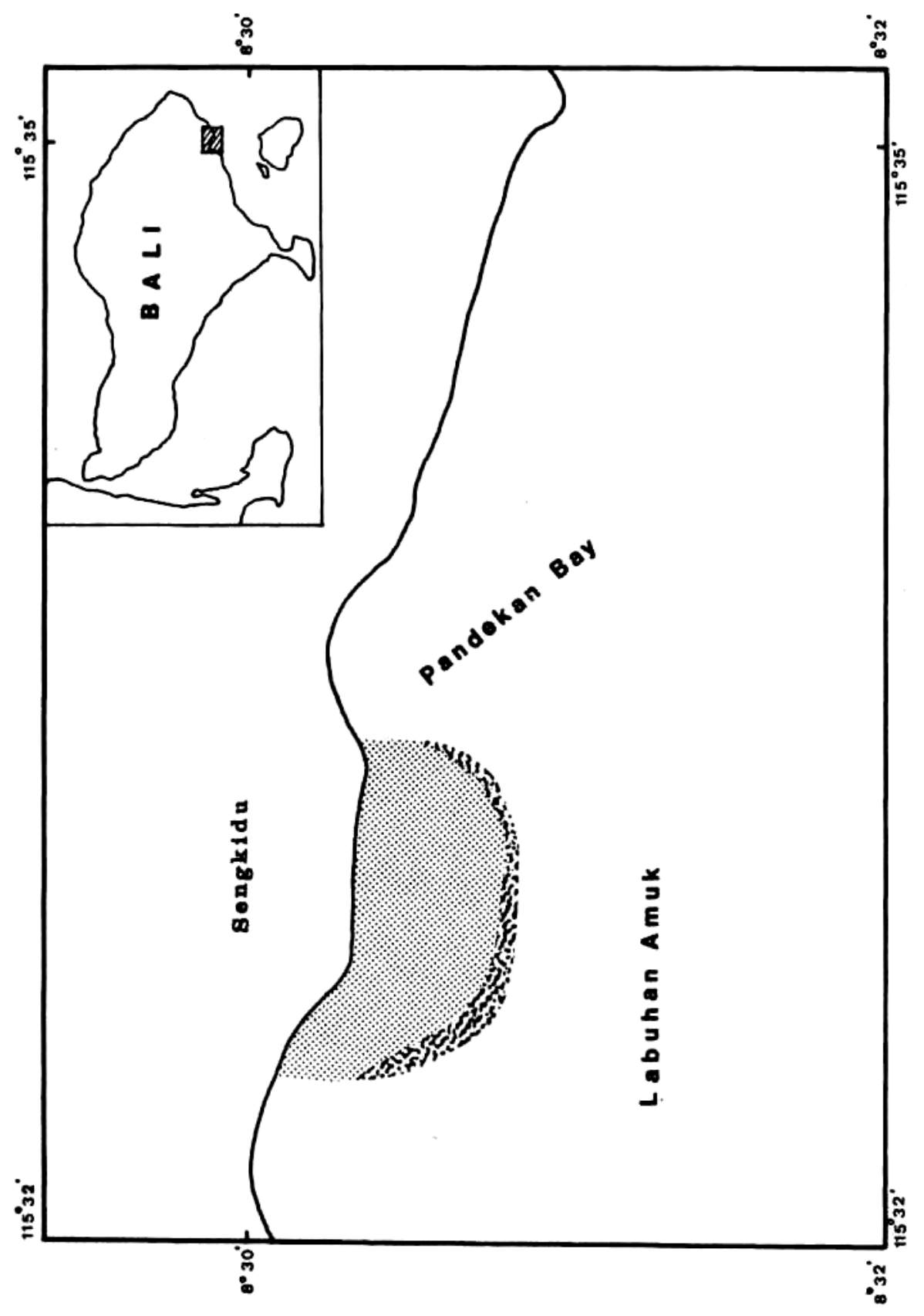

Figure 1. Sengkidu beach, Labuan Amuk, east coast of Bali. 


\section{OBSERVATION ON BEACH EROSION}

\section{THE INVESTIGATED AREA}

Sengkidu is a small village near the coast on the eastern part of the Bali Island $\left(115^{\circ} 33^{\prime} 30^{\prime \prime} \mathrm{E}-08^{\circ} 30^{\prime} 20^{\prime \prime} \mathrm{S}\right)$. The studied reef flat is streched in an east-west direction parallel to the shore-line between Labuan Amuk and Pandekan Bay (Fig. 1). The reef flat is approximately $1 \mathrm{~km}$ long and forms a barrier at a distance of $150 \mathrm{~m}$ off the coast. From the coast, the reef flat is rather horizontal and gradually sloping toward the sea. Water depths varies between 1 to $3 \mathrm{~m}$ depending on the tide.

Living coral is limited to areas of hard rock which are not covered by sand. The corals consist mainly of small colonies of Acropora. The number of colonies increases toward the sea. On the seaward slope the colonies become bigger.

According to the local inhabitants, some decades ago a "puri" (temple) was built on the coast of Sengkidu. Due to beach erosion the temple is now about $100 \mathrm{~m}$ away from the shore (Fig. 2).

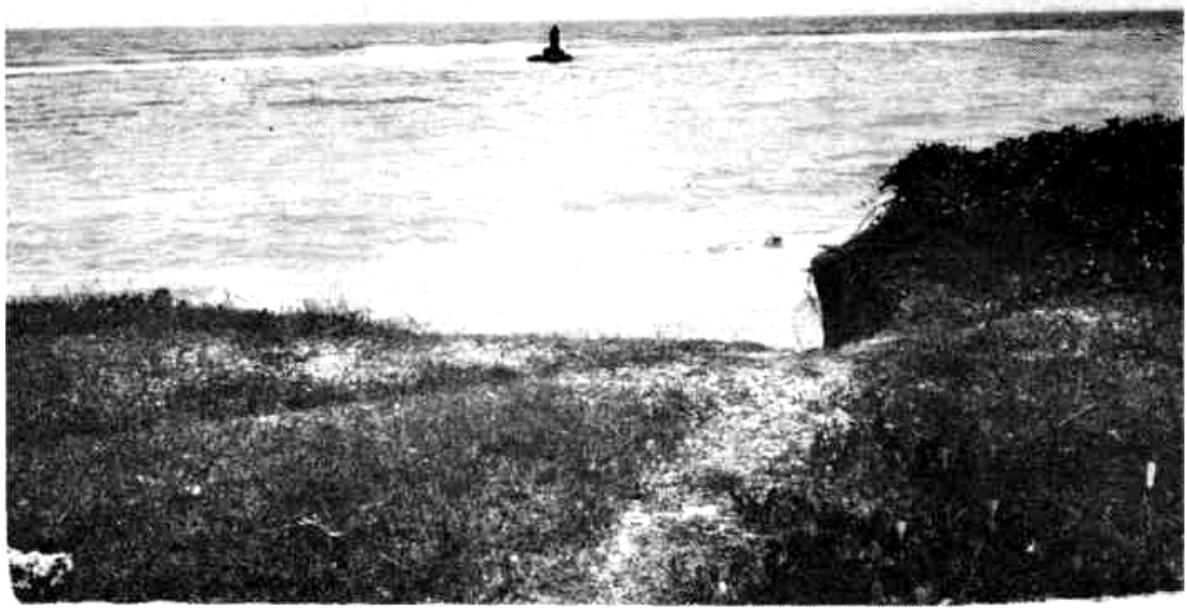

Figure 2. A "puri" (temple) originally built on the coast of Sengkidu is presently seen on a distance of approximately $100 \mathrm{~m}$ off the shore. 


\section{DJOKO P. PRASENO \& SUKARNO}

\section{MATERIALS AND METHODS}

The aerial photographs were taken using a multispectral camera (Fig. 3). The camera consists of four lenses, each equipped with four different filters. Blue, green, red, and infra-red filters were used for our purpose. The film used was a Black \& White film which is also sensitive to infra-red spectrum.

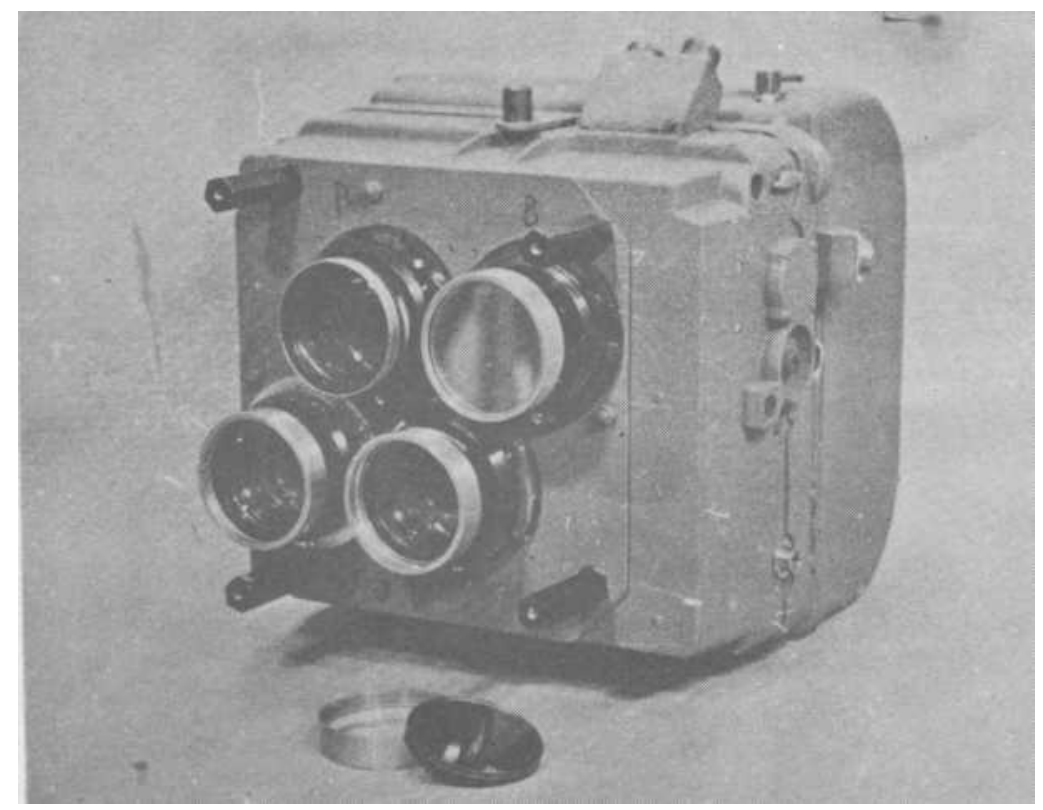

Figure 3. The multispectral camera. A camera with four lenses, each equipped with different filters.

Each of the four spectral negatives was taken at the same instant by the four matched lenses. Four spatially identical negatives were produced, since the optical axes of the lenses were normal to the film plane. The obtained images were identical except for the densities which differ partly due to the selective spectral reflectance of ground objects.

The mission was flown at an altitude of 8,000 feet at 09.30. Low hanging clouds prevented flight to be carried out earlier and higher. Earlier experiments showed that good results were obtained when the photographs were taken early in the morning between $07.00-08.00$ local time (SZEKIELDA et al 1974).

At the same time ground truth was made by surveying the area. A rough map was drawn showing the distribution of coral and the conditions of both coral and beach. 
OBSERVATION ON BEACH EROSION

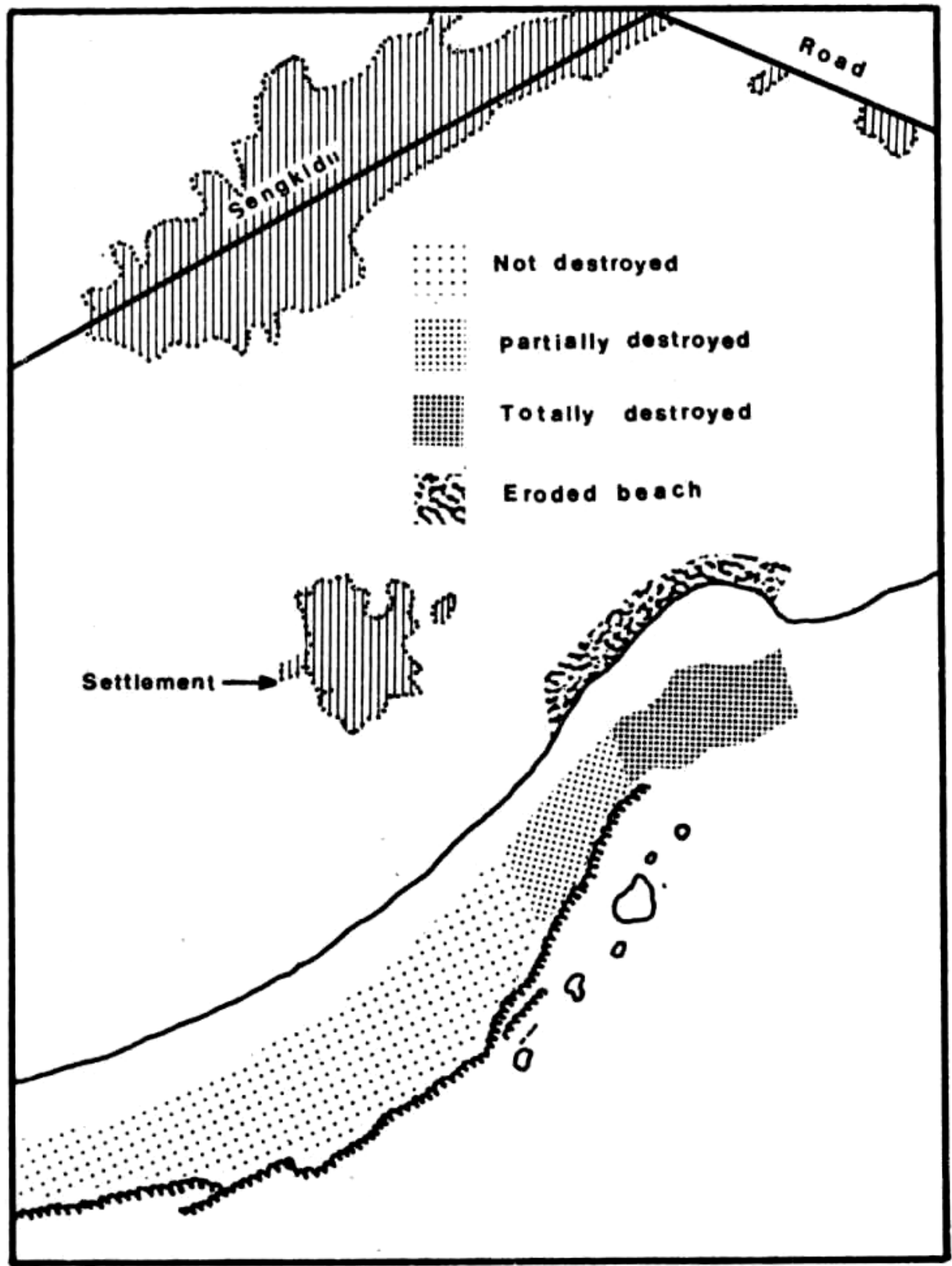

Figure 4. Coral destruction and beach erosion at Sengkidu analyzed from aerial photographs (see also figure 6) 


\section{DJOKO P. PRASENO \& SUKARNO}

\section{RESULTS AND DISCUSSION}

Images obtained through the infra-red filter shows the best results. Features above sea level can be seen nicely. Reefs are usually studied by observing the breaking of waves on the reef. On some spots, however, this feature does not show up. These may be interpreted as des-tructed coral reef. On those spots the waves are clearly seen passing over destructed coral and acting their force on the beach. Figure 4 shows the area of totally destructed coral, partially destructed, and non-destructed areas. Figure 5 shows the eroded beach and piles of mined coral laying on the beach ready to be transported.

Images taken with the blue and green filters shows turbidity patterns of the sea water. The passing waves are not clearly seen due to signals received from the turbidity patterns. Turbidity is likely caused by the eroding effects. Bottom features are not visible on areas of destructed corals. But on non-destructed areas some bottom features are still seen.

Eighteen species of stony corals are recorded from Sengkidu waters (Table I). The most dominant genus is Acropora. Seven species of the genus are recorded, i.e. Acropora latistella (BROOK) A. smithi

Table I. List of stony coral found at Sengkidu Beach, Labuan Amuk, east coast of Bali.

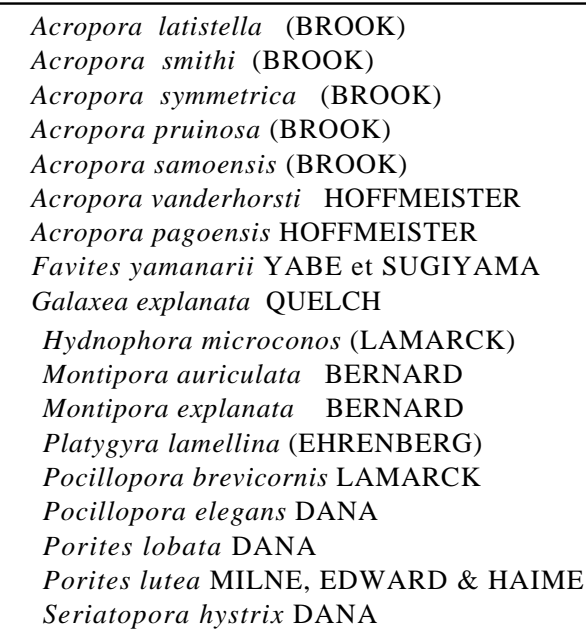

(BROOK), A. symmetrica (BROOK), A. pruinosa (BROOK), A. samoensis (BROOK), A. vanderhosti HofFMeISTER, and A. pagoensis HOFFMEISTER. Next dominant corals are two species of Montipora, i.e. Montipora auriculata BERNARD and M. explanata BERNARD, Porites lutea MILNE EDWARD \& HAIME and P. lobata DANA also form an important member of the stony corals of Sengkidu waters. 


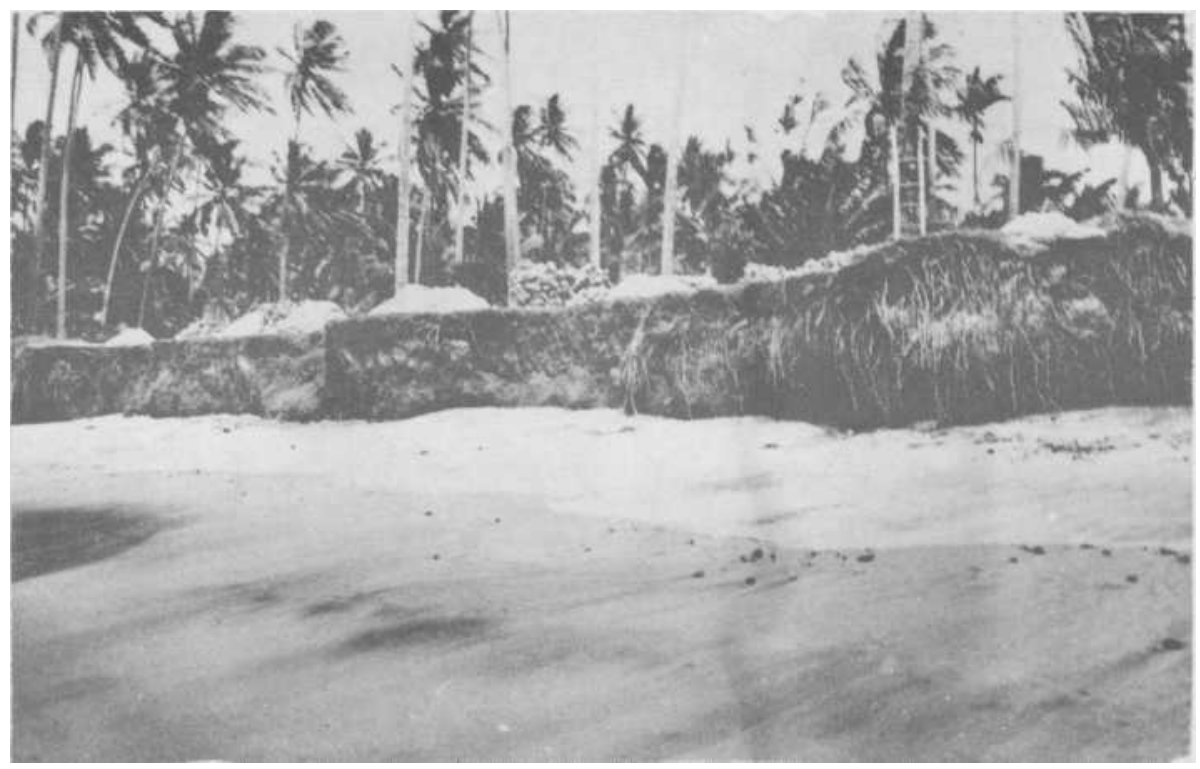

Figure 5. Eroded beach and piles of mined coral.

Ground truth observations shows that destruction of the reef occurs also due to other causes. One possible cause of earlier destruction is the drop in $\mathrm{pH}$ of the sea water. This is caused by the Gunung Agung eruption. The lava following eruption enters the sea near Sengkidu Beach. The drop in sea water $\mathrm{pH}$ due to the lava stream is not tolerated by the corals causing the destruction. After the eruption the corals starts to recover. This can be seen from the small sized colonies of stony coral scatters on the reef flat. On the seaward slope toward the sea, the colonies became bigger by depth. This suggests that only the upper layers are exposed to the low $\mathrm{pH}$.

From the study made at Sengkidu Beach, it is proven that aerial photography forms a perfect tool for determining coral reefs. Even satellite imagery can be used to locate coral reefs (SZEKIELDA et al 1974). It is, indeed, true that sometimes it is difficult to interpret ERTS - 1 imagery (satellite imagery) for areas near river mouths. River discharge and mud in the near coastal areas do not allow sharp contrast in the reflective properties in the infra-red band. Generally, location of reefs and their distance from the coast are in agreement with common maps.

To locate reefs, infra-red spectrum is found best suitable, since it will record all features above sea level. The breaker's zone of the reef 


\section{DJOKO P. PRASENO \& SUKARNO}

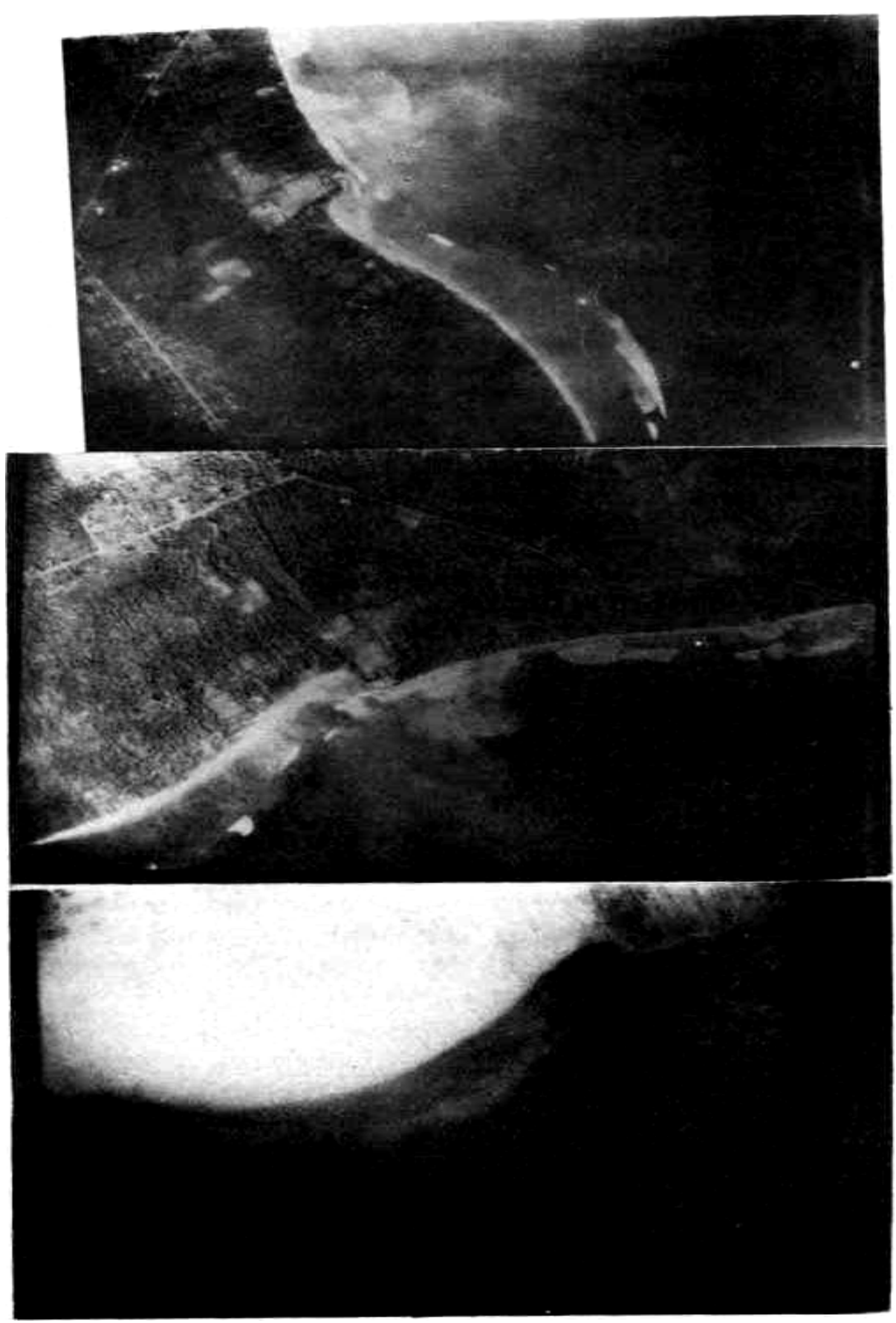

Figure 6. Aerial photographs of Sengkidu Beach taken through three different filters: blue (a), green (b), and infra-red (c). See test for explanation. 
can then be located accurately. The red spectrum penetrates the water for a few centimeters which will also indicate coral distribution. However, suspended sediment near the surface will interfere the signals obtained from waves, and waves will show less sharp. The green and blue spectra may be used to study conditions of coral reef. Both spectra are able to penetrate sea water and so catch signals from the bottom of the sea. Both spectra are able to penetrate water to some meters, depending on water transparancies. On areas where beach erosion occurs, plumes of suspensions will interfere the reflections from the bottom, and bottom features will not be clearly seen.

Clouds may also form a problem in remote sensing. This is the case during the Bali project. The second part of the project was flown during the rainy season. Low hanging clouds prevented missions to be flown as was scheduled.

if coral collecting activities are continued, the beach will suffer heavier damage from eroding affects of waves and currents. A rapid change of coast line will happen that will destroy plantations near the coast. On the other hand, it will be difficult to prevent people from collecting corals, since the activity constitutes one of their major livelihood. The collecting activities should be localized to the inner side of the reef flat, saving those living on the breaker's zone. The collections should be limited to dead corals only.

\section{ACKNOWLEDGEMENT}

I would express my thanks to Prof. KARDONO DARMOJOEWONO and staff of BAKOSURTANAL for all the advices, placing of laboratory facilities at my disposal, and other friendly help. My thanks also goes to Dr. SzEKIELDA for his advices and guidance. To Dr. APRILANI SOEGIARTO and Mr. SUJATNO BIROWO of the National Institute of Oceanology for their encouragement. And to Mr. NURACHMAD HADI for his help on the ground truth survey.

\section{REFERENCES}

ANDERSON, D.M., L.W. CATTO, H.L. Mc KIM, and A. PETRONE 1973. Sediment distribution and coastal processes in Coak Inlet, Alaska. Symp. on Significant Results obtained from ERTS-1, 1, sect. $B: 1323$ - 1339.

BOWKER, D.E., P. FLEISHER, T.A. GOSNIK, W.J. HANNA, and J. LUDWICK 1973. Correlation of ERTS-1 multispectral imagery with suspended matter and chlorophyll in Lower Chesapeake Bay. Symp. on Significant Results obtained from ERTS-i, 1, sect. B : 1291-1298.

BROWN, W.L., F.C. POLCYN, and S.R. STEWART 1971. A method for calculating water depths, attenuation coefficient, and bottom reflectance characteristics. Proc. 7th Intern. Symp. Rem. Sens. Environm. 1 : 663-681. 


\section{DJOKO P. PRASENO \& SUKARNO}

HUNTER, R.E. 1973. Distribution and movement of suspended sediment in the Gulf of Mexico off the Texas Coast. Symp. on Significant Results obtained from ERTS-1, 1, sect. B : 1341-1348.

MASCARENHAS, A.S. Jr. and K. TANAKA 1974. Use of ERTS-1 images in coastal studies in Guanabara Bay and adjacent waters. Seminar on Space Applications of Direct Interest to Developing Countries, Brasil: 823-831.

PRASENO, D.P. 1975. A study on pollution in the Jakarta Bay and its vicinity based on ERTS-1 imagery Proceedings of the Joint UN/FAO Regional Seminar on Remote Sensing Applications, Jakarta, Vol.11 : 241-250. 19-28 Nov. 1975.

ROSS,D.S. 1973. Water depth estimation with ERTS-1 imagery. Symp. on Significant Results obtained from ERTS1, 1, sect. B : 1423-1432.

SZEKIELDA, K.H., D.P. PRASENO, and N. NAAMIN 1974. Multispectral photography in oceanography. Testsite Bali. Preliminary report on remote sensing project in Bali (unpublished). 30 pp.

WRIGHT, F.F., G.D. SHARMA, and D.C. BURBANK 1973. ERTS-1 observations of sea surface circulation and sediment transport, Coak Inlet. Alaska. Symp. on Significant Results obtained from ERTS-I, l , sect. B: $1315-1322$.

YOST, E., R. ANDERSON, R. KALIA, V. POSTERARO, and S. WENDEROTH 1971. Multispectral photographic remote sensing of coastal environments. Technical Report SERG. TR-II, Long Island University: 286 